\title{
Supervisi Kolaboratif dapat Meningkatkan Kompetensi Profesional Guru
}

\author{
Uud Solehudin ${ }^{1^{*}}$ iD \\ ${ }^{1}$ SD Negeri 1 Sidaraja, Kuningan, Indonesia \\ *Corresponding author: solehudin768@gmail.com
}

\begin{abstract}
Tujuan penelitian ini adalah sebagai berikut :1) untuk mengetahui perkembangan proses supervisi kolaboratif untuk meningkatkan kompetensi profesional guru Tahun Pelajaran 2019/2020, 2) Untuk meningkatan kompetensi profesional guru setelah diterapkan pendekatan supervisi kolaboratif. Dalam penelitian ini yang menjadi subyek penelitian adalah 10 guru yang memiliki karakteristik bahwa kompetensi profesionalnya rendah khususnya dalam mengembangkan materi pembelajaran. Namun, guru di sekolah ini dapat bekerja secara kolaboratif dan memiliki motivasi untuk selalu merefleksi kinerjanya serta berbagi pengalaman dengan rekan sejawatnya. Berdasarkan pembahasan dalam penelitian mengenai penerapan pendekatan supervisi kolaboratif untuk meningkatkan kompetensi profesional guru dapat ditarik beberapa simpulan sebagai berikut: Proses supervisi dengan menerapkan pendekatan supervisi kolaboratif secara spesifik terdiri dari tahap pra-supervisi kolaboratif, supervisi kolaboratif dan pasca-supervisi kolaboratif. Proses supervisi dengan menerapkan pendekatan supervisi kolaboratif mengalami perkembangan dari siklus 1 ke siklus 2.
\end{abstract}

Keywords: Supervisi, Kompetensi Profesional Guru

\section{Abstract}

The objectives of this study are as follows: 1) to determine the development of the collaborative supervision process to improve teacher professional competence for the 2019/2020 Academic Year, 2) To increase teacher professional competence after implementing a collaborative supervision approach. In this study, the research subjects were 10 teachers who had the characteristics that their professional competence was low, especially in developing learning materials. However, teachers in this school can work collaboratively and have the motivation to always reflect on their performance and share experiences with their peers. Based on the discussion regarding the application of the collaborative supervision approach to improve teacher professional competence, the conclusions can be drawn as follows: The supervision process by applying a collaborative supervision approach specifically consists of the collaborative pre-supervision, collaborative supervision and post-collaborative supervision stages. The supervision process by applying a collaborative supervision approach has increased from cycle 1 to cycle 2.

Keywords: Supervision, Teacher Professional Competence

$\begin{array}{lll}\text { History: } & & \text { Publisher: Undiksha Press } \\ \text { Received } & : 4 \text { April } 2020 & \text { Licensed: This work is licensed under } \\ \text { Revised } & : 1 \text { Mei } 2020 & \text { a Creative Commons Attribution 3.0 License } \\ \text { Accepted } & : \text { 20 Juli } 2020 & \end{array}$




\section{Introduction}

Pendidikan adalah usaha sadar yang dilakukan oleh seseorang secara sistematis untuk menghasilkan manusia yang berkualitas. Pendidikan yang berkualitas tidak bisa terlepas dari peranan guru. Guru menjadi penentu berhasil atau tidaknya pembelajaran yang ia jalankan karena guru berperan sebagai motivator, fasilitator, dan inspirator bagi peserta didik, sehingga guru menjadi sosok yang dapat dicontoh oleh peserta didiknya (Babuta \& Rahmat, 2019; Prayitno, 2019). Guru yang profesional bukan sekedar sebagai alat untuk transmisi kebudayaan akan tetapi mentransformasikan kebudayaan itu ke arah budaya yang dinamis dan menuntut penguasaan ilmu pengetahuan dan teknologi, produktivitas yang tinggi dan kualitas karya yang mampu meningkatkan daya saing (Damsik, 2017; Darma, 2017). Ketersediaan guru yang profesional dalam banyak hal akan berpengaruh terhadap peningkatan kualitas pendidikan, kinerja guru dan hasil belajar siswa (Damsik, 2017).

Profesionalisme seorang guru perlu diupayakan untuk peningkatan mutu pendidikan karena proses pembelajaran yang tidak tepat menjadi salah satu penyebab kurang optimalnya prestasi belajar siswa (Tanama et al., 2016). Peningkatan profesionalisme guru dapat dilakukan dengan kegiatan supervisi (Ansori et al., 2016; Tanama et al., 2016). Supervisi mengandung beberapa kegiatan pokok, yaitu pembinaan yang berkelanjutan, pengembangan kemampuan profesional guru, perbaikan situasi belajar mengajar dengan sasaran akhir pencapaian tujuan pendidikan dan pertumbuhan pribadi peserta didik (Nugraha, 2015; Istibsjaroh \& Agustina, 2013).

Berdasarkan hasil refleksi diri yang telah dilakukan oleh peneliti sebagai kepala sekolah, selama ini kepala sekolah melaksanakan tugas supervisi akademiknya dengan menerapkan pendekatan supervisi langsung secara individual, dengan cara mendatangi guru yang sedang bertugas, mengamati kinerjanya dan melakukan penilaian. Pendekatan supervisi individual ini tidak terlalu efektif untuk meningkatkan kompetensi guru dalam melaksanakan tugasnya khususnya yang berkaitan dengan kompetensi profesionalnya. Hasil kajian empirik yang peneliti lakukan terhadap guru-guru di SDN 1 Sidaraja Kabupaten Kuningan menunjukkan bahwa kompetensi profesional guru masih rendah terutama pada kompetensi guru dalam mengembangkan materi pembelajaran yang diampu secara kreatif. Rata-rata kemampuan guru dalam mengembangkan materi pembelajaran yang diampunya berdasarkan penilaian kinerja guru terhadap 10 orang guru di SDN 1 Sidaraja Kabupaten Kuningan, diperoleh data sebagai Tabel 1.

Tabel 1. Kompetensi Guru dalam Mengembangkan Materi Pembelajaran

\begin{tabular}{clcc}
\hline \multirow{2}{*}{ No. } & \multicolumn{1}{c}{ Aspek } & \multicolumn{2}{c}{ Rata-rata } \\
\cline { 3 - 4 } & & Skala 4 & Skala 100 \\
\hline A. & Keterurutan & 2,14 & 53,41 \\
\hline B. & Keberjenjangan & 2,27 & 56,82 \\
\hline C. & Kedalaman & 1,77 & 44,32 \\
\hline D. & Keluasan & 2,18 & 54,55 \\
\hline & Nilai Rata-rata Keseluruhan & 2,09 & 52,27 \\
\hline
\end{tabular}

Hasil analisis data pada tabel di atas menunjukkan bahwa kompetensi guru dalam mengembangkan materi pembelajaran yang diampu masih pada kategori sedang yaitu indeks rata-rata 2,09 atau 52,27. Hasil refleksi terhadap temuan tersebut menunjukkan bahwa faktor yang menyebabkan masih rendahnya kompetensi guru tersebut diduga disebabkan oleh faktor internal dan eksternal. Faktor internal yang diduga mempengaruhi rendahnya kompetensi 
profesional guru antara lain: 1) Guru belum memahami teknik pengembangan materi pembelajaran; 2) Guru tidak melakukan analisis materi pembelajaran sebelum mengembangkan bahan ajar atau materi pembelajaran; dan 3) Kurangnya motivasi diri guru untuk melakukan kinerja profesionalnya dengan baik.

Faktor eksternal yang diduga mengakibatkan rendahnya kompetensi profesional guru adalah pelaksanaan supervisi oleh kepala sekolah yang lebih bersifat menilai. Idealnya, supervisi dilaksanakan secara kolegial, tidak menggurui, bersifat kemitraan dan pendampingan, serta dilakukan melalui diskusi dan curah pendapat secara terbuka dan fleksibel untuk membantu guru merefleksi kinerjanya dalam melaksanakan tugas profesionalnya (Utami, 2017). Profesionalisme terdiri atas pengetahuan dan pemahaman mengenai sikap terhadap profesi kemudian ditunjukkan dalam lima unjuk kerja sebagai berikut: (1) keinginan untuk selalu menampilkan perilaku yang mendekati standar ideal; (2) meningkatkan dan memelihara citra profesi; (3) keinginan untuk mengejar kesempatan pengembangan profesional yang dapat meningkatkan dan memperbaiki kualitas pengetahuan dan keterampilan; (4) mengejar kualitas dan cita-cita profesi; dan (5) memiliki kebanggaan terhadap profesinya (Setiawan \& Sitorus, 2017).

Efektivitas pelaksanaaan kinerja profesional guru sangat bergantung pada kompetensi kepala sekolah dalam melaksanakan tugasnya diantaranya dalam melakukan supervisi akademik. Untuk melaksanakan supervisi akademik, kepala sekolah sebagai supervisor dan penanggungjawab kegiatan di sekolah harus mampu menyusun program, melaksanakan, dan melakukan tindak lanjut supervisi akademik di sekolah yang dipimpinnya. Pelaksanaan supervisi akademik yang baik oleh kepala sekolah akan menghasilkan kompetensi guru dalam memfasilitasi pembelajaran yang baik pula. sehingga keberhasilan siswa dalam pembelajaran sangat bergantung pada kemampuan guru dalam memfasilitasi pembelajaran dan kompetensi kepala sekolah dalam melaksanakan supervisi akademik (Prayitno, 2019; Hadi, 2019; Merukh \& Sulasmono, 2016; Muspawi, 2017). Esensi supervisi akademik itu bukan menilai kinerja guru dalam mengelola proses pembelajaran, melainkan membantu guru mengembangkan kemampuan profesionalismenya (Prayitno, 2019).

Kompetensi supervisi akademik kepala sekolah terdiri dari tiga aspek yaitu kompetensi dalam menyusun program, melaksanakan, mengevaluasi dan menindaklanjuti temuan-temuan ketika melaksanakan supervisi akademiknya. Program supervisi akademik yang harus disusun oleh seorang kepala sekolah merupakan pedoman atau acuan dalam melaksanakan supervisi akademik. Selain itu, program supervisi akademik juga dapat mengembangkan kemampuan guru dalam mengelola pembelajaran secara efektif. Dari hasil pelaksanaan supervisi akademik, kepala sekolah juga harus mampu merefleksi kinerjanya dan melaksanakan tindak lanjut sebagai umpan balik yang sangat berguna untuk peningkatan kualitas baik bagi siswa, guru, maupun dirinya yang pada akhirnya dapat meningkatkan kualitas pendidikan di sekolahnya (Prayitno, 2019).

Beberapa penelitian mengenai supervisi akademik diantaranya penelitian yang dilakukan oleh (Prayitno, 2019) menyatakan bahwa pelaksanaan supervisi akademik oleh kepala sekolah dapat meningkatkan pedagogi guru. Kemudian penelitian yang dilakukan oleh Hadi (2019) menemukan bahwa supervisi kunjungan kelas oleh kepala sekolah berpengaruh positif dan signifikan terhadap peningkatan kinerja guru. Penelitian yang dilakukan oleh Muspawi (2017) menemukan bahwa implementasi supervisi akademik di MAN Insan Cendekia Provinsi Jambi telah terlaksana dengan baik sehingga menghasilkan kinerja guru yang juga baik.

Berdasarkan uraian di atas, untuk mengatasi masalah rendahnya kompetensi profesional guru dalam melaksanakan tugas profesionalnya, maka diterapkan tindakan berupa pendekatan supervisi yang belum pernah dilakukan sebelumnya yaitu pendekatan supervisi kolaboratif. 


\section{Materials and Methods}

Metode penelitian yang digunakan pada penelitian ini adalah metode Penelitian Tindakan Sekolah (PTS) dengan model Kemmis dan Mc. Taggart yang merupakan model pengembangan dari model Kurt Lewin. Dikatakan demikian, karena di dalam suatu siklus terdiri atas empat komponen, keempat komponen tersebut, meliputi: (1) perencanaan, (2) aksi/ tindakan, (3) observasi, dan (4) refleksi. Setelah suatu siklus selesai diimplementasikan, khususnya sesudah adanya refleksi, kemudian diikuti dengan adanya perencanaan ulang yang dilaksanakan dalam bentuk siklus tersendiri.

Penelitian ini dilakukan di SDN 1 Sidaraja Kabupaten Kuningan yang memiliki karakteristik bahwa di sekolah ini kepala sekolah selalu melakukan supervisi akademik secara individual, tidak secara kolaboratif padahal karakteristik guru di sekolah ini adalah dapat bekerja secara kolaboratif dan memiliki motivasi untuk selalu merefleksi kinerjanya dan berbagi pengalaman dengan rekan sejawatnya. Dalam penelitian ini yang menjadi subyek penelitian adalah 10 guru di SDN 1 Sidaraja Kabupaten Kuningan yang memiliki karakteristik bahwa kompetensi profesionalnya rendah khususnya dalam mengembangkan materi pembelajaran. Namun, guru di sekolah ini dapat bekerja secara kolaboratif dan memiliki motivasi untuk selalu merefleksi kinerjanya serta berbagi pengalaman dengan rekan sejawatnya. Jadwal pelaksanaan penelitian tindakan sekolah dengan menerapkan pendekatan supervisi kolaboratif untuk meningkatkan kompetensi profesional guru telah dikoordinasikan dan disepakati bersama 10 guru yaitu pada bulan Agustus s.d. September 2019 (2 bulan).

Faktor-faktor yang diteliti dalam PTS ini adalah proses supervisi kolaboratif yang terkait dengan keterlaksanaan prinsip-prinsip supervisi kolaboratif yaitu prinsip kolaboratif, kolegial, kemitraan, terbuka dan fleksibel pada ketiga tahapan supervisi kolaboratif yang terdiri dari tahap pra-supervisi kolaboratif, supervisi kolaboratif dan pasca-supervisi kolaboratif. Selain hal tersebut, faktor lain yang diteliti adalah kompetensi profesional guru dalam mengembangkan materi pembelajaran. Alat pengumpul data yang digunakan untuk mengumpulkan data yang berkaitan dengan variabel yang diteliti adalah: Lembar observasi, lembar catatan lapangan dan pedoman wawancara. Data yang telah terkumpul kemudian di olah dengan teknik pengolahan dan analisis data dilakukan secara kuantitatif dan kualitatif. Teknik pengolahan data secara kuantitatif dilakukan terhadap variabel kompetensi profesional guru. Data yang diperoleh dari hasil pengamatan atau observasi kinerja profesional guru dalam mengembangkan materi pembelajaran yang terdiri dari empat aspek yaitu keterurutan, keberjenjangan, kedalaman, dan keluasan diolah dengan menentukan nilai rata-ratanya. Analisis data kompetensi profesional guru dilakukan menggunakan prosentase $(\%)$, yakni perhitungan yang digunakan untuk mengetahui tingkat prosentase skor penilaian dari masing-masing indikator kompetensi profesional guru dalam mengembangkan materi pembelajaran. Rumus yang digunakan adalah sebagai berikut:

$$
\text { Prosentase }(\%)=\frac{\sum n}{N} \text { X } 100 \%
$$

Dimana:

$$
\begin{aligned}
& \sum \mathrm{n}=\text { Jumlah skor jawaban responden } \\
& \mathrm{N}=\text { Jumlah skor jawaban ideal } \\
& \%=\text { Tingkat persentase }
\end{aligned}
$$

(Mohammad Ali, 1987:184)

Data kuantitatif berupa prosentase tersebut kemudian dijadikan dasar untuk dikonversi kedalam data kualitatif menggunakan kriteria Tabel 2. 
Tabel 2. Kriteria Kompetensi Profesional Guru

\begin{tabular}{cc}
\hline Skor & Kriteria \\
\hline $91-100$ & Sangat Baik \\
\hline $76-90$ & Baik \\
\hline $61-75$ & Cukup \\
\hline $51-60$ & Kurang \\
\hline$\leq 50$ & Sangat Kurang \\
\hline
\end{tabular}

\section{Results and Discussion}

Penelitian tindakan sekolah ini dilakukan dalam dua siklus. Berikut merupakan deskripsi hasil penelitian tindakan sekolah terkait dengan proses supervisi dengan menerapkan pendekatan supervisi kolaboratif pada siklus 1 dan 2 .

\section{Proses Supervisi Kolaboratif pada Siklus 1}

Supervisi kolaboratif pada siklus 1 ini dilaksanakan pada tanggal 3 Agustus s.d. 3 September 2019. Pendekatan supervisi kolaboratif pada siklus 1 dilaksanakan dengan menerapkan kesepuluh prinsip pendekatan supervisi kolaboratif yaitu prinsip kolaboratif, kolegial, kemitraan, terbuka dan fleksibel melalui tahapan-tahapan spesifik sebagai berikut:

1. Tahap pra-supervisi kolaboratif, kepala sekolah bersama 10 guru melaksanakan curah pendapat dan diskusi di sekolah difasilitasi oleh kepala sekolah tentang masalah-masalah krusial guru dalam mengembangkan materi pembelajaran dan bahan ajar.

2. Tahap supervisi kolaboratif, kepala sekolah melaksanakan supervisi kolaboratif bersama guru pada saat guru sedang melaksanakan kinerja profesionalnya dengan menerapkan kelima prinsip pendekatan supervisi kolaboratif yaitu prinsip kolaboratif, kolegial, kemitraan, terbuka dan fleksibel.

3. Tahap pasca-supervisi kolaboratif, kepala sekolah bersama 10 guru melaksanakan refleksi pelaksanaan kinerja profesionalnya difasilitasi oleh kepala sekolah.

Temuan-temuan selama proses supervisi kolaboratif berlangsung dikumpulkan menggunakan lembar observasi proses supervisi kolaboratif dan catatan lapangan. Peneliti sebagai observer mengamati keterlaksanaan supervisi dengan menerapkan pendekatan supervisi kolaboratif yang selanjutnya memberikan deskripsi pada kolom yang telah disediakan pada lembar observasi proses supervisi kolaboratif. Untuk lebih jelasnya, Tabel 3. berikut adalah deskripsi hasil pengamatan peneliti sebagai observer:

Tabel 3. Deskripsi Hasil Observasi Proses Supervisi dengan Menerapkan Pendekatan Supervisi Kolaboratif pada Siklus 1

\begin{tabular}{|c|c|c|}
\hline No & Tahapan Spesifik & Temuan \\
\hline 1 & $\begin{array}{l}\text { Tahap Pra-Supervisi } \\
\text { Kolaboratif }\end{array}$ & $\begin{array}{l}\text { Seluruh guru tidak membawa daftar masalah terkait kompetensi } \\
\text { profesionalnya dalam mengembangkan materi pembelajaran dan } \\
\text { bahan ajar, curah pendapat dan diskusi tidak berjalan dengan baik, } \\
\text { hanya satu orang guru yaitu G05 yang aktif mencurahkan } \\
\text { pendapatnya }\end{array}$ \\
\hline 2 & $\begin{array}{l}\text { Tahap Pelaksanaan } \\
\text { Supervisi Kolaboratif }\end{array}$ & $\begin{array}{l}\text { Guru G03 dan G07 tidak menyiapkan hasil analisis materi } \\
\text { pembelajaran yang telah disusunnya sehingga mengganggu proses } \\
\text { supervisi kolaboratif }\end{array}$ \\
\hline 3 & $\begin{array}{l}\text { Tahap Pasca-Supervisi } \\
\text { Kolaboratif }\end{array}$ & $\begin{array}{l}\text { Seluruh guru terlibat dalam proses refleksi pelaksanaan supervisi } \\
\text { kolaboratif dengan menyampaikan temuan dan pemecahannya }\end{array}$ \\
\hline
\end{tabular}

\section{Proses Supervisi Kolaboratif pada Siklus 2}

Supervisi kolaboratif pada siklus 2 ini dilaksanakan pada tanggal 10 s.d. 24 Oktober 2019. Pendekatan supervisi kolaboratif pada siklus 2 dilaksanakan berdasarkan rekomendasi- 
rekomendasi pada siklus 1 dengan menerapkan kesepuluh prinsip pendekatan supervisi kolaboratif yaitu prinsip kolaboratif, kolegial, kemitraan, terbuka dan fleksibel melalui tahapan-tahapan spesifik sebagai berikut:

1. Tahap pra-supervisi kolaboratif, kepala sekolah terlebih dahulu melakukan koordinasi dengan semua guru dan menjelaskan teknis supervisi kolaboratif yang akan dilaksanakan diantaranya mengindentifikasi masalah-masalah krusial ketika melaksanakan kinerja profesionalnya dalam mengembangkan materi pembelajaran dan bahan ajar, mencatat dan membawanya pada saat curah pendapat dan diskusi bersama kepala sekolah dan guru lainnya. Selanjutnya, kepala sekolah bersama 10 guru melaksanakan curah pendapat dan diskusi difasilitasi oleh kepala sekolah tentang masalah-masalah krusial yang teridentifikasi oleh guru dalam melaksanakan kinerja profesionalnya. Pada akhir tahap pra-supervisi kolaboratif, kepala sekolah menguatkan dan menegaskan kepada guru untuk menyiapkan kelengkapan diantaranya hasil analisis materi pembelajaran.

2. Tahap supervisi kolaboratif, kepala sekolah melaksanakan supervisi kolaboratif bersama guru pada saat guru lain sedang melaksanakan kinerja profesionalnya dengan menerapkan kelima prinsip pendekatan supervisi kolaboratif yaitu prinsip kolaboratif, kolegial, kemitraan, terbuka dan fleksibel.

3. Tahap pasca-supervisi, kepala sekolah bersama 10 guru melaksanakan refleksi pelaksanaan kinerja profesional dan supervisi kolaboratif difasilitasi oleh kepala sekolah.

Temuan-temuan selama proses supervisi kolaboratif berlangsung dikumpulkan menggunakan lembar observasi proses supervisi kolaboratif dan catatan lapangan. Peneliti sebagai observer mengamati keterlaksanaan supervisi dengan menerapkan pendekatan supervisi kolaboratif yang selanjutnya memberikan deskripsi pada kolom yang telah disediakan pada lembar observasi proses supervisi kolaboratif. Untuk lebih jelasnya, deskripsi hasil pengamatan peneliti sebagai observer dapat dilihat pada Tabel 4.

Tabel 4. Deskripsi Hasil Observasi Proses Supervisi dengan Menerapkan Pendekatan Supervisi Kolaboratif pada Siklus 2

\begin{tabular}{|c|c|c|}
\hline No & Tahapan Spesifik & Temuan \\
\hline 1 & $\begin{array}{l}\text { Tahap Pra-Supervisi } \\
\text { Kolaboratif }\end{array}$ & $\begin{array}{l}\text { Curah pendapat dan diskusi berjalan dengan baik, seluruh guru aktif } \\
\text { berdiskusi dan mencurahkan pendapatnya }\end{array}$ \\
\hline 2 & $\begin{array}{l}\text { Tahap Pelaksanaan } \\
\text { Supervisi Kolaboratif }\end{array}$ & $\begin{array}{l}\text { Pelaksanaan supervisi kolaboratif berjalan dengan efektif, guru } \\
\text { mampu menerapkan solusi-solusi dari masalah yang teridentifikasi } \\
\text { sebelumnya sebagai hasil curah pendapat dan diskusi dengan guru } \\
\text { lain dan kepala sekolah pada tahap pra-supervisi kolaboratif. }\end{array}$ \\
\hline 3 & $\begin{array}{l}\text { Tahap Pasca-Supervisi } \\
\text { Kolaboratif }\end{array}$ & Seluruh guru terlibat dalam proses refleksi \\
\hline
\end{tabular}

Pada siklus 2 ini tidak ditemukan lagi temuan-temuan negatif, dan pelaksanaan supervisi kolaboratif sudah sesuai dengan tahapan-tahapan spesifik supervisi kolaboratif. Tabel 5 merupakan perkembangan temuan selama proses supervisi dengan menerapkan pendekatan supervisi kolaboratif dari siklus 1 ke siklus 2.

Tabel 5 Perkembangan Temuan selama Proses Supervisi dengan Menerapkan Pendekatan Supervisi Kolaboratif

\begin{tabular}{cll}
\hline Tahapan & \multicolumn{1}{c}{ Siklus 1 } & \multicolumn{1}{c}{ Siklus 2 } \\
\hline & Seluruh guru tidak membawa daftar masalah & Curah pendapat dan diskusi berjalan \\
Pra-Supervisi & terkait kinerja profesionalnya, curah pendapat & dengan baik, seluruh guru aktif \\
Kolaboratif & $\begin{array}{l}\text { datiskusi tidak berjalan dengan baik, hanya } \\
\text { satu guru yaitu G05 yang aktif mencurahkan } \\
\text { pendapatnya }\end{array}$ & $\begin{array}{l}\text { berdiskusi dan mencurahkan } \\
\text { pendapatnya }\end{array}$ \\
\hline
\end{tabular}




\begin{tabular}{cll}
\hline Tahapan & \multicolumn{1}{c}{ Siklus 1 } & \multicolumn{1}{c}{ Siklus 2 } \\
\hline $\begin{array}{c}\text { Pelaksanaan } \\
\text { Supervisi }\end{array}$ & $\begin{array}{l}\text { Guru G03 dan G07 tidak menyiapkan } \\
\text { kelengkapan berupa hasil analisis materi } \\
\text { pembelajaran sehingga mengganggu proses } \\
\text { Kolaboratif }\end{array}$ & $\begin{array}{l}\text { Pelaksanaan supervisi kolaboratif } \\
\text { berjalan dengan efektif, guru mampu } \\
\text { menerapkan solusi-solusi dari masalah } \\
\text { yang teridentifikasi sebelumnya sebagai } \\
\text { hasil curah pendapat dan diskusi dengan } \\
\text { guru lain dan kepala sekolah pada tahap } \\
\text { pra-supervisi kolaboratif. }\end{array}$ \\
& & $\begin{array}{l}\text { Seluruh guru terlibat dalam proses } \\
\text { refleksi }\end{array}$ \\
Pasca- & $\begin{array}{l}\text { Seluruh guru terlibat dalam proses refleksi } \\
\text { pelaksanaan supervisi kolaboratif dengan } \\
\text { Kolaboratif }\end{array}$ & menyampaikan temuan dan pemecahannya \\
\hline
\end{tabular}

Berdasarkan temuan tersebut, Tabel 6 merupakan perkembangan proses supervisi kolaboratif dari siklus 1 ke siklus 2 yang mengalami perkembangan terutama pada tahap prasupervisi kolaboratif.

Tabel 6. Perkembangan Proses Supervisi dengan Menerapkan Pendekatan Supervisi Kolaboratif

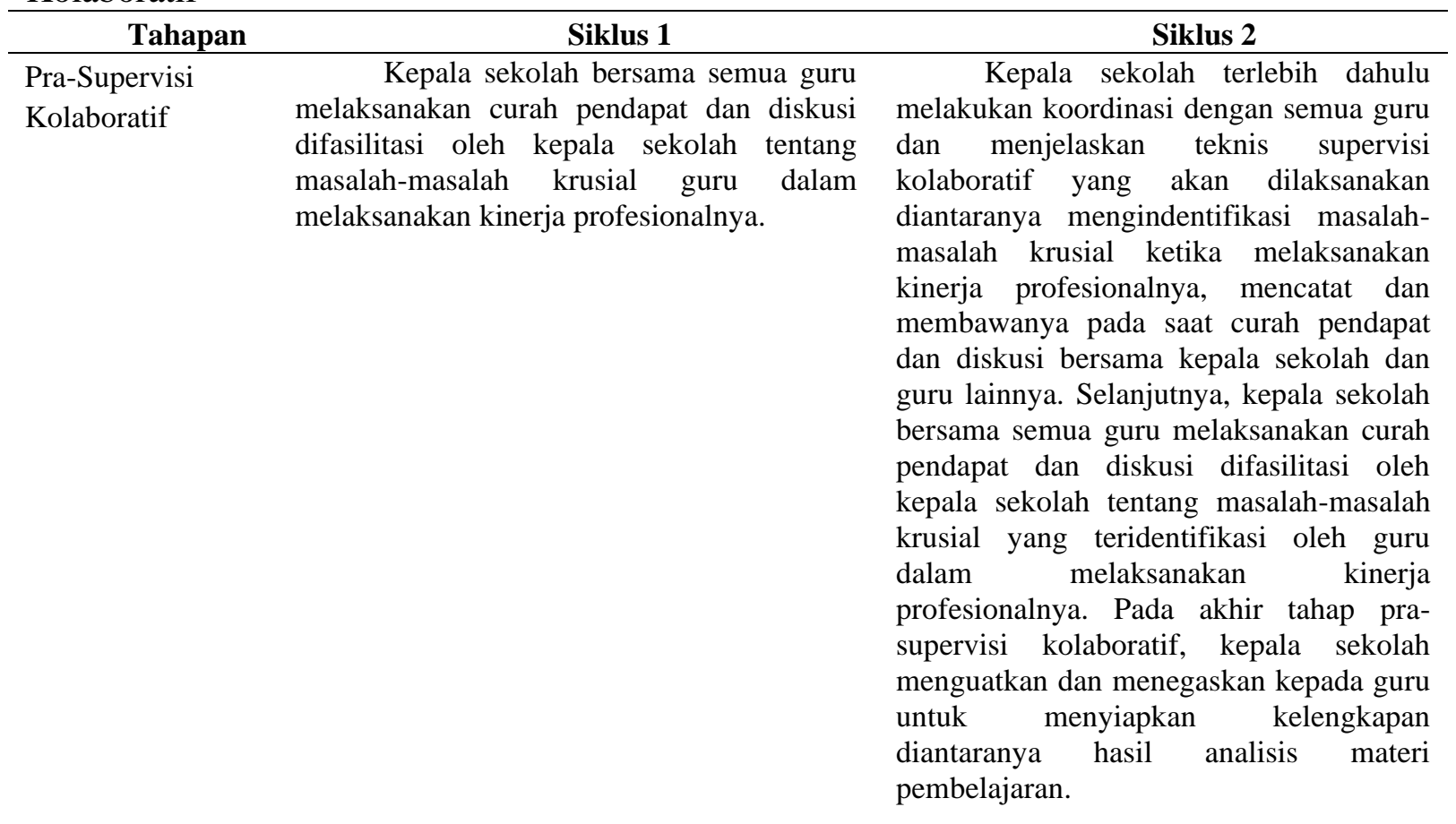

\section{Kompetensi Profesional Guru pada Siklus 1}

Kompetensi profesional guru ini terdiri dari kemampuannya dalam mengembangkan materi pembelajaran dan bahan ajar. Kompetensi guru dalam melaksanakan kinerja profesionalnya diamati dan diukur menggunakan lembar observasi kinerja profesional guru dalam mengembangkan materi pembelajaran dan bahan ajar. Gambar 1 merupakan rata-rata kompetensi profesional guru di SDN 1 Sidaraja Kabupaten Kuningan yang diukur dan diamati terhadap 10 guru. 


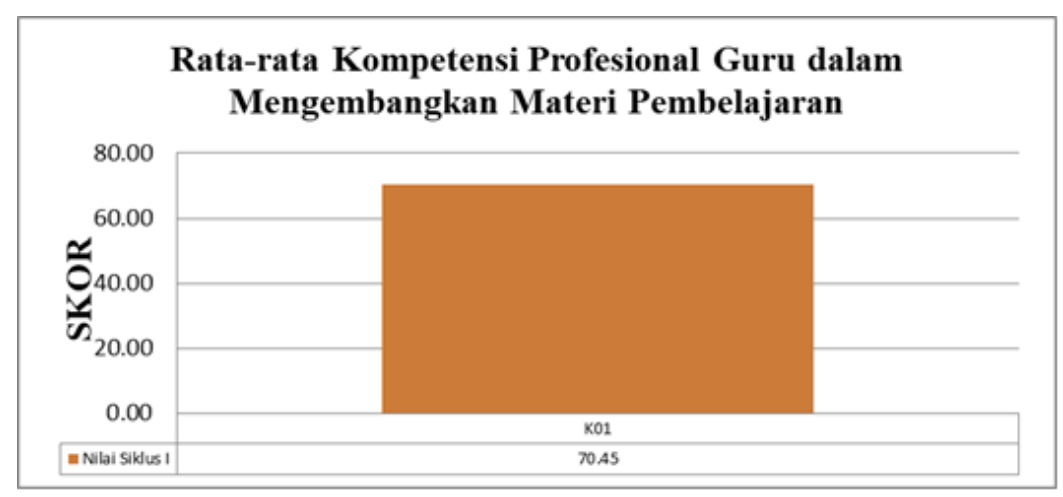

Gambar 1. Grafik Rata-rata Kompetensi Profesional Guru dalam Mengembangkan Materi Pembelajaran pada Siklus 1

Pada Gambar 1 terlihat skor rata-rata kompetensi profesional guru dalam mengembangkan materi pembelajaran dan bahan ajar sebesar 70,45 dengan kriteria cukup. Hal ini menunjukkan bahwa kemampuan guru dalam mengembangkan materi pembelajaran dan bahan ajar setelah diterapkan pendekatan supervisi kolaboratif sudah cukup baik. Berbeda dengan sebelum diterapkan pendekatan supervisi kolaboratif, rata-rata kompetensi guru dalam mengembangkan materi pembelajaran dan bahan ajar sebesar 52,27 dengan kriteria kurang. Hal ini menunjukkan bahwa pendekatan supervisi kolaboratif dapat meningkatkan kompetensi profesional guru dalam mengembangkan materi pembelajaran dan bahan ajar.

\section{Kompetensi Profesional Guru pada Siklus 2}

Seperti halnya pada siklus 1, Kompetensi profesional guru yang diukur adalah kemampuan guru dalam mengembangkan materi pembelajaran dan bahan ajar. Kompetensi profesional guru ini diamati dan diukur menggunakan lembar observasi kinerja profesional guru dalam mengembangkan materi pembelajaran dan bahan ajar. Gambar 2 merupakan ratarata kompetensi profesional guru di SDN 1 Sidaraja Kabupaten Kuningan yang diukur dan diamati terhadap 10 guru.

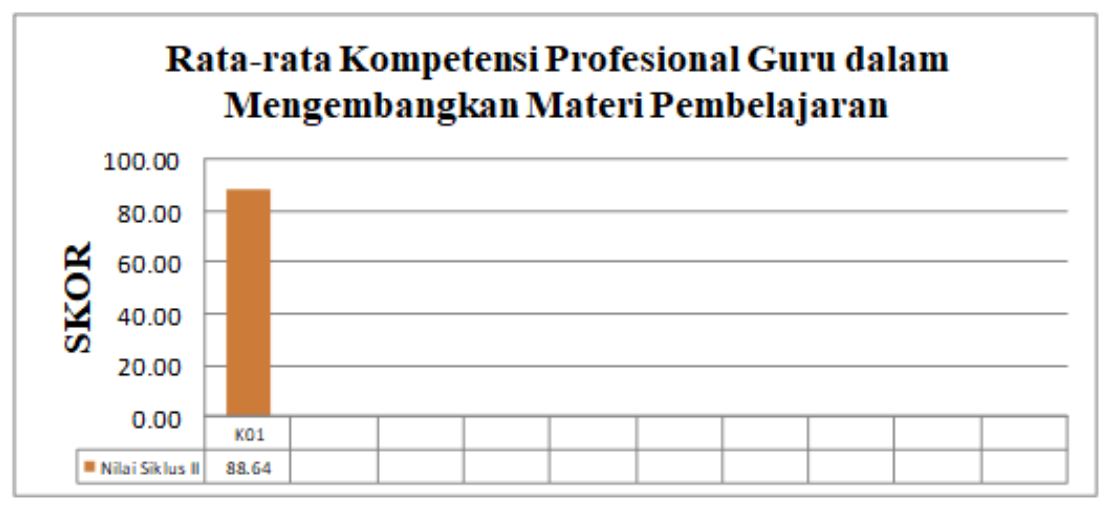

Gambar 2. Grafik Rata-rata Kompetensi Profesional Guru dalam Mengembangkan Materi Pembelajaran pada Siklus 2

Pada gambar 2 terlihat bahwa skor rata-rata kompetensi profesional guru dalam mengembangkan materi pembelajaran dan bahan ajar sebesar 88,64 dengan kriteria baik. Hal ini menunjukkan bahwa kemampuan guru dalam mengembangkan materi pembelajaran dan bahan ajar pada siklus 2 setelah diterapkan pendekatan supervisi kolaboratif sudah baik. 
Berbeda dengan siklus 1, rata-rata kompetensi profesional guru dalam mengembangkan materi pembelajaran dan bahan ajar sebesar 70,45 dengan kriteria cukup baik. Hal ini menunjukkan bahwa pendekatan supervisi kolaboratif dapat meningkatkan kompetensi profesional guru dalam mengembangkan materi pembelajaran dan bahan ajar.

Kompetensi profesional guru mengalami peningkatan dari pra-siklus, siklus 1 sampai dengan siklus 2. Tabel 7 dan Gambar 3 merupakan peningkatan kompetensi profesional guru dari sebelum dilakukan tindakan (pra-siklus) sampai dengan setelah diterapkan tindakan berupa pendekatan supervisi kolaboratif (siklus 1 dan 2).

Tabel 7. Peningkatan Kompetensi Profesional Guru

\begin{tabular}{cccc}
\hline Kompetensi & Pra-siklus & Siklus 1 & Siklus 2 \\
\hline Rata-rata & 52,27 & 70,45 & 88,64 \\
\hline Kriteria & Kurang & Cukup & Baik \\
\hline
\end{tabular}

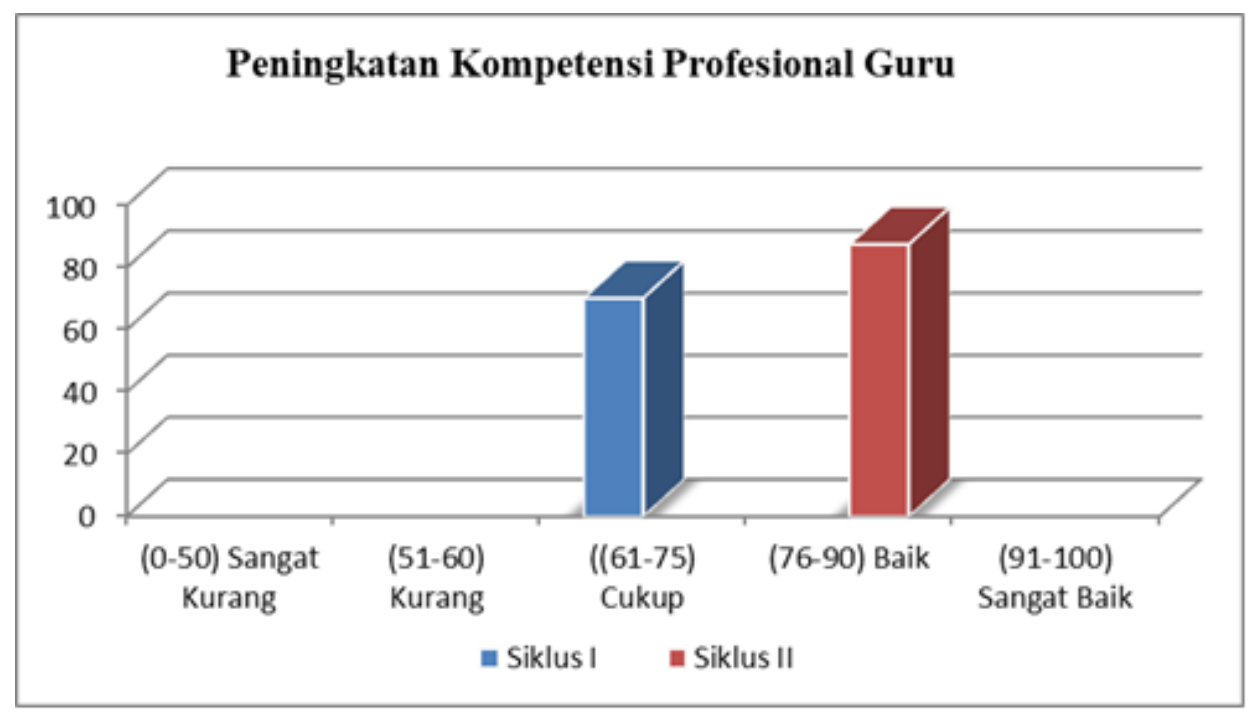

Gambar 3. Grafik Peningkatan Kompetensi Profesional Guru

Tabel 7 dan Gambar 3 menunjukkan bahwa kompetensi profesional guru mengalami peningkatan dari pra-siklus ke siklus 1 dan dari siklus 1 ke siklus 2 . Hal ini diduga bahwa pendekatan supervisi kolaboratif telah dilaksanakan secara efektif selamat proses supervisi baik pada tahap pra-, pelaksanaan, dan pasca-supervisi kolaboratif.

Berdasarkan hasil penelitian yang sudah dibahas sebelumnya dapat dikatakan bahwa terdapat dampak yang positif terhadap profesionalisme guru. Dengan adanya bimbingan dari kepala sekolah dapat meningkatkan kualitas kinerja guru. Beberapa penelitian mengenai supervisi akademik diantaranya penelitian yang dilakukan oleh Prayitno (2019) menyatakan bahwa pelaksanaan supervisi akademik oleh kepala sekolah dapat meningkatkan pedagogi guru. Kemudian penelitian yang dilakukan oleh Hadi (2019) menyatakan bahwa supervisi kunjungan kelas oleh kepala sekolah berpengaruh positif dan signifikan terhadap peningkatan kinerja guru.

Beberapa penelitian mengenai supervisi kolaboratif seperti penelitian yang dilakukan oleh Kosman (2019) menyatakan bahwa Pelaksanaan supervisi edukatif kolaboratif secara periodik dapat meningkatkan kinerja guru dalam menyusun rencana pembelajaran dan melaksanakan pembelajaran di kelas sehingga berdampak pada meningkat pula hasil belajar siswa. Kemudian penelitian yang dilakukan oleh Dwikurnaningsih \& Hartana (2018) 
menyatakan bahwa pelaksanaan supervise akademik dengan pendekatan kolaboratif yang dilaksanakan oleh kepala sekolah dapat meningkatkan kualitas pembelajaran yang dilakukan guru. Penelitian yang dilakukan oleh Rukayah (2018) menyatakan bahwa terjadi peningkatan kompetensi guru kelas bawah SD Negeri Ungaran 05 Kecamatan Ungaran Barat Kabupaten Semarang dalam merencanakan pembelajaran tematik sebagai dampak dari dilaksanakannya supervisi kelompok dengan pendekatan kolaboratif.

\section{Conclusion}

Berdasarkan pembahasan dalam penelitian mengenai penerapan pendekatan supervisi kolaboratif untuk meningkatkan kompetensi profesional guru di SDN 1 Sidaraja Proses supervisi dengan menerapkan pendekatan supervisi kolaboratif secara spesifik terdiri dari tahap pra-supervisi kolaboratif, supervisi kolaboratif dan pasca-supervisi kolaboratif. Proses supervisi dengan menerapkan pendekatan supervisi kolaboratif mengalami perkembangan dari siklus 1 ke siklus 2. Pada tahap pra-supervisi kolaboratif siklus 1 , curah pendapat tidak berjalan dengan efektif karena kepala sekolah tidak melakukan koordinasi dengan semua guru dan tidak menjelaskan teknis supervisi kolaboratif yang akan dilaksanakan diantaranya mengidentifikasi masalah-masalah krusial ketika guru melaksanakan kinerja profesionalnya, mencatat dan membawanya pada saat curah pendapat dan diskusi bersama kepala sekolah dan guru lainnya. Kemudian pada siklus 2, kepala sekolah melakukan koordinasi dengan semua guru dan menjelaskan teknis supervisi kolaboratif yang akan dilaksanakan serta menguatkan dan menegaskan kepada guru untuk menyiapkan kelengkapan terkait kinerja profesionalnya sehingga curah pendapat dan diskusi berjalan dengan tertib dan efektif. Pada tahap supervisi kolaboratif siklus 1, proses supervisi kolaboratif terhambat karena guru tidak membawa kelengkapan terkait kinerja profesionalnya, sedangkan pada siklus 2 mereka membawa semua kelengkapan sehingga pelaksanaan supervisi kolaboratif berjalan dengan tertib. Pada tahap pasca-supervisi kolaboratif, kepala sekolah tidak koordinatif dengan semua guru dan tidak berhasil memotivasi guru untuk saling belajar. Sedangkan pada siklus 2, kepala sekolah mulai koordinatif dengan semua dan berhasil memotivasi guru untuk saling belajar.

\section{References}

Ansori, A., Supriyanto, A., \& Burhanuddin, B. (2016). Pelaksanaan Supervisi Klinis Dalam Meningkatkan Kinerja Guru Sekolah Dasar. Jurnal Pendidikan:Teori, Penelitian, Dan Pengembangan, $1(12)$, 2321-2326. https://doi.org/http://dx.doi.org/10.17977/jp.v1i12.8285.

Babuta, A. I., \& Rahmat, A. (2019). Peningkatan Kompetensi Pedagodik Guru Melalui Pelaksanaan Supervisi Klinis Dengan Teknik Kelompok. Al-Tanzim: Jurnal Manajemen Pendidikan Islam, 3(1), 1-28. https://doi.org/10.33650/al-tanzim.v3i1.496.

Damsik, M. G. (2017). Penerapan Supervisi Klinis untuk Perbaikan Kegiatan Belajar Mengajar di Madrasah Aliyah Paradigma Palembang. Conciencia, 17(2), 46-57.

Darma, A. (2017). Perilaku Profesional Guru Progresif. Potensia Jurnal Kependidikan Islam, $3(2)$.

Dwikurnaningsih, Y., \& Hartana, N. (2018). Supervisi Akademik Melalui Pendekatan Kolaboratif Oleh Kepala Sekolah Dalam Meningkatkan Kualitas Pembelajaran Guru di SD. Satya Widya, 34(2). https://doi.org/10.24246/j.sw.2018.v34.i2.p101-111.

Hadi, S. (2019). Supervisi Akademik Kunjungan Kelas Oleh Kepala Sekolah Dalam Rangka Meningkatkan Kinerja Guru ( Studi Kasus Di SMP NW Jerua ). Fondatia: Jurnal Pendidikan

Dasar,

$3(2)$,

114-135. 


\section{https://doi.org/https://doi.org/10.36088/fondatia.v3i2.371.}

Istibsjaroh, I., \& Agustina, P. (2013). Peran Kepala Sekolah Dalam Supervisi Pendidikan Agama Islam Pada Kegiatan Belajar Mengajar Di Sma Negeri Bareng Jombang. Journal of Chemical Information and Modeling, 53(9), 1689-1699. https://jurnal.stituwjombang.ac.id/index.php/al-idaroh/article/view/50.

Kosman, K. (2019). Upaya Meningkatkan Kinerja Guru Dalam Pembelajaran Melalui Supervisi Edukatif Kolaboratif Secara Periodik. Jurnal Educatio FKIP UNMA, 5(1), 3743. https://doi.org/https://doi.org/10.31949/educatio.v5i1.34.

Merukh, N., \& Sulasmono, B. S. (2016). Pengembangan Model Supervisi Akademik Teknik Mentoring Bagi Pembinaan Kompetensi Pedagogik Guru Kelas. Kelola: Jurnal Manajemen Pendidikan, 3(1), 30. https://doi.org/10.24246/j.jk.2016.v3.i1.p30-48.

Muspawi, M. (2017). Implementasi Supervisi Akademik pada MAN Insan Cendekia Provinsi Jambi. Ta'dib: Jurnal Pendidikan Islam, 6(2), 49-56. https://doi.org/10.29313/tjpi.v6i2.3181.

Nugraha, M. S. (2015). Pelaksanaan Supervisi Akademik oleh Kepala Madrasah Aliyah Swasta di Kabupaten Sukabumi Jawa Barat. Nadwa, 9(1). https://doi.org/10.21580/nw.2015.9.1.520.

Prayitno, P. J. (2019). Pelaksanaan Supervisi Akademik Untuk Meningkatkan Kompetensi Pedagogik Guru SMA. Jurnal Visi Ilmu Pendidikan, 11(2), 46. https://doi.org/10.26418/jvip.v11i2.33209.

Rukayah, R. (2018). Peningkatan Kompetensi Guru Dalam Perencanaan Pembelajaran Tematik Melalui Supervisi Kelompok Pendekatan Kolaboratif. Kelola: Jurnal Manajemen Pendidikan, 5(1), 37-46. https://doi.org/10.24246/j.jk.2018.v5.i1.p37-46.

Setiawan, D., \& Sitorus, J. (2017). Urgensi Tuntutan Profesionalisme Dan Harapan Menjadi Guru Berkarakter (Studi Kasus: Sekolah Dasar dan Sekolah Menengah Pertama di Kabupaten Batubara). Jurnal Cakrawala Pendidikan, 36(1), 122-129. https://doi.org/10.21831/cp.v36i1.11382.

Tanama, Y. J., Supriyanto, A., Universitas, M. P., \& Malang, N. (2016). Implementasi Supervisi Klinis Dalam. Jurnal Pendidikan: Teori, Penelitian, Dan Pengembangan, 1(11), 2231-2235. https://doi.org/http://dx.doi.org/10.17977/jp.v1i11.8127.

Utami, S. (2017). Penerapan Supervisi Klinis untuk Meningkatkan Kinerja Guru dalam Proses Belajar Mengajar Gugus IV Sanankulon. Briliant: Jurnal Riset Dan Konseptual, 2(3). https://doi.org/10.28926/briliant.v2i3.70. 